\title{
Alternatives of different refinement and transmission system applications in refining and reusing of wastewater at Namık Kemal University
}

\author{
Abdullah YINANÇ ${ }^{1}$ \\ ${ }^{1}$ Namık Kemal University, Vocational College of Technical Sciences, Dept. of Construction Technology, 59030 \\ - Süleymanpaşa-Tekirdăg, Turkey. \\ Corresponding author: ayinanc@nku.edu.tr
}

\begin{abstract}
In order to achieve sustainable goals, the detection and application of methods, which could reduce or bar waste of water, wastewater and waste electricity, are very important in establishing techniques and systems which could be used to combine social and economic aims with ecological needs. The wastewater of university is a kind of domestic wastewater, and at least $60 \%$ of the total wastewater usage consists of grey water, and this water will be reused. Domestic wastewater will primarily be collected in 2 different systems. These could be two side by side piping systems, as well as a different system to be obtained by passing a smaller diameter pipe through the same pipe. As material in this system; Waste water storage tank, "discontinuous suction and force pump", A different suction pipe for negative purposes and all kinds of materials, All the equipment of the existing wastewater treatment plant will be used. The more the demands and standards of environment rise, the more necessary it has become to figure out and apply effectively different and innovative solutions. Particularly, it is really important for the countries or cities whose foundation of facilities or running those facilities cost a lot to be able to reuse wastewater. For example, the need for water increased by $45 \%$ in Istanbul (Turkey) and increased by $20 \%$ in Sydney (Australia) and 14, $8 \%$ in Monterrey (Mexico) in the last ten years (2008, OECD research). It is seen that, in the countries where tourism has developed, the usage of electricity overnight is between 3-6 kWh per bed and water 600-1300 liters per bed. Ultra-refining, combined purification and transmission technology (membrane, UV, transmission by vacuum etc.) which have been reconstructed and used after the 1990s, have been researched within the scope of the present study. Reactivating the existing water purification system at Namık Kemal University central campus, which is convenient for daily usage in the summer months, and ultra refining method purified from bacteria and utility of the systems that are determined to use in the transfer of wastewater, have been presented comparatively in the present research.
\end{abstract}

Key words: Reuse, vacuum canal system, grey water, membrane

Özet

Sürdürülebilir hedeflere ulaşmada; Su, atıksu, elektrik ve fazla atık oluşumunu azaltan veya önleyen metotların belirlenip uygulanması, sosyal ve ekonomik hedefleri, ekolojik gereksinimlerle birleştirecek yönetim ve sistemlerin uygulanması ve elde edilen ürünlerin kullanılabilmesi büyük önem arz etmektedir. Artan çevresel talepler ve standartlar ise, farklı ve yenilikçi çözümlerin bulunarak verimli bir şekilde kullanılmasını zorunlu hale getirmiştir. Özellikle, yüksek ilk yatırım ve işletme masraflarına neden olan teknolojilere ihtiyaç duyan ülke ya da şehirlerde atık suyun tekrar kullanıma sunulması önem taşımaktadır. Zira; Su ihtiyacı artışı son 10 yılda, İstanbul da (Türkiye) \%45, Sydney (Avustralya) \%20, Monterrey (Meksiko) \%14.8 oranındadır ( 2008, OECD araştırması).Turizmi gelişmiş bölgelerde gecelik yatak başına su tüketimi 600-1300 litre/ yatak ve enerji tüketimi 3-6 kWh mertebesini bulmaktadır. Su ve atıksu tarifeleri ve enerji tüketim maliyetleri özellikle de desalinizasyon sistemlerinin olduğu yerlerde çok daha yüksek olmaktadır. Üniversite kampüsünde kullanım amaçlı su bulunmamaktadır. Üniversite atıksuları evsel nitelikli atıksu olup toplam su kullanımının en az \%60 kadarını oluşturmakta, bu sular tekrar kullanılabilecek grisu sulardır. Evsel atık sular öncelikle 2 farklı sistemle 
toplanacaktır. Bunlar yan yana 2 boru sistemi olabileceği gibi, aynı borunu içine daha küçük çaplı diğer bir boru geçirilerek elde edilecek farklı bir sistemden de oluşacaktır. Sistem de; Atık su biriktirme deposu "kesikli emme basma tulumba/pompa", negatif etki için farklı emme borusu ile mevcut atıksu arıtma tesisinin tüm ekipmanı kullanılacaktır. Bu çalışma; 1990’lı yıllardan sonra yeniden yapılandırılan ve kullanılmış suları arıtan kombine arıtma ve iletim teknolojisi (membran, UV, vakum, iletim vb.) nin kullanımının araştırılmasını içermektedir. Namık Kemal Üniversitesi Merkez Kampusünde, yaz aylarında günlük ihtiyaç için atıksuların arıtma sisteminden geçirilmesi ve bakterilerden arıtılarak arıtılmış suyun uygun yerlere transfer edilerek kullanımı amaçlanmaktadır.

Anahtar kelimeler: Yeniden kullanma, vakum kanal sistemi, gri su, membran

\section{Introduction}

When water consumption of domestic and industrial facilities is pondered upon, the reuse of wastewater once it is processed through treatment facilities are of great importance depending on environmental standards. The demands and needs of human beings must be set on a sustainable growth policy. It is of utmost importance to reduce the consumption of water and to establish systems that produce less waste instead of classical technologies that produce more liquid and solid waste. The issue of recycling and reuse of wastewater is becoming an increasingly common concern not only in dense urban areas but also in rural areas as well when limited water resources and increasing water demands are taken into consideration (Yinanç and Adiloğlu 2017, Adiloğlu 2016).

It is unfortunately well accepted today that, pollution at national and also international level is on a dramatic increase. Water pollution is a result of dumping of industrial wastes, natural and artificial compounds, used to increase yield, into water resources (Sağlam and Bellitürk, 2003, Adiloğlu et al. 2017). Reducing the rate of removal and discharge of fresh water from sensitive ecosystems by reusing wastewater, reusing recycled water for irrigation, reducing pollution and contribution to pollution reduction could be said to be the basic aim of this study.

This study has two main objectives. These are special and general purposes. The general purpose of this study is the development of qualified socio-cultural infrastructure services and sustainability of habitable environments, increasing the quality of life at university, and the creation of a modern and an exemplary university with a green building concept that benefits from clean and renewable energy sources. The special purpose of the study is through the construction of an "Ecological Domestic Wastewater Treatment System" at Namık Kemal University's Değirmenaltı Campus, it is aimed to decrease our carbon footprints by refining our wastewater which causes the diminishing clean water resources to get polluted if wastewater is not processed and cleaned and to be exemplary to local authorities to build similar facilities by displaying the benefits of this kind of facilities.

\section{Description of identified needs and problems}

Only $3 \%$ of the world's water is fresh water and only $1 \%$ of it is easily accessible. As a university, we also have to use our limited natural resources efficiently.

Considering that rapidly decreasing water resources are very important for humanity, it is possible to use the wastewater in various areas provided that they meet certain criteria after having been purified by subjecting them to appropriate treatment.

$99 \%$ of domestic wastewater is water and $1 \%$ is composed of organic and inorganic mixtures.

Thrace Region is threatened by pollution caused by population increase, industry, agriculture and crooked urbanization and other environmental adverse effects even though it is in a rich position in terms of natural resources as compared to its geographic position.

Problems such as water pollution, air pollution, waste pollution, soil pollution, noise pollution and destruction of natural environment in the Trakya Region in the province of Tekirdag are presented 
as priorities in environmental problems in 2012 "Environment Problems and Priorities Inventory Evaluation Report" (2012 "Turkey Environmental Problems and Priorities Inventory Evaluation Report")

The waters of central campus of Namık Kemal University will be prevented from being left untreated to the receiving environment, the wastewater will be purified by the system to be installed and the more efficient use of limited natural resources will be ensured.

It is planned to reduce the water cost of about 1 million EURO per year by $40 \%$ and to provide an income of 400000 EURO per year while avoiding environmental pollution with efficient use of treated water.

On the campus, the green area of $105000 \mathrm{~m}^{2}$ will be increased to $200000 \mathrm{~m}^{2}$ and the green area and the amount of trees will be increased by $100 \%$, leading to the utilization of ecological, environmentally sensitive and environmentally friendly systems.

\section{Target groups and final beneficiaries}

Namık Kemal University, as of 2017, NKU has 35 thousand students, 2000 employees, 170000 hectares of central campus and 200000 hectares of other campus areas with a total area of approximately 370000 hectares. It has a continuous growth of 3500-4000 students per year and concordantly daily water consumption steadily increases.

Tekirdağ Metropolitan Municipality has a population of about 970 thousand people, while Süleymanpaşa District in the center is a city where 192300 people from different income groups live.

Namık Kemal University is in a position where water consumption is continuously increasing with the increasing number of students and employees every day. Water demands create water pressure. For this purpose, it needs a system for the treatment of wastewater.

\section{Re-use and waste water recovery}

It is very important to recycle wastewater especially the grey water for re-use. Because in this case the cost of water decreases considerably. Managing water, wastewater and energy resources to meet the needs of today's and future users' is crucial in terms of sustainability.

Domestic wastewater collected with sewage systems is put into use following the treatment. These waters are particularly used in places such as green areas and trees.

However, when these waters are used we pay attention to some issues.

- Affordable and economical solutions for use,

- The cyclical cost of assessing wastewater as a source for energy and water recovery

- Ensuring water saving and reusing with efficient use of water,

- Issues such as integrated water, waste and energy management, recycling, and resource efficiency are important issues.

Regardless of the type of wastewater, the use of vacuum systems wastewater technology is of great importance for collection and treatment of wastewater and for use after treatment. 
Table 1. Logical Framework

\begin{tabular}{|c|c|c|c|c|}
\hline & Working logic & $\begin{array}{l}\text { Measurable } \\
\text { İndicators }\end{array}$ & $\begin{array}{c}\text { Validation sources } \\
\text { and tools }\end{array}$ & Assumptions \\
\hline 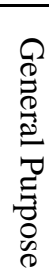 & $\begin{array}{l}\text { The main objective of this study is } \\
\text { to improve the quality of } \\
\text { infrastructure services and ensure } \\
\text { the sustainability of the livable } \\
\text { environment and contribute to the } \\
\text { quality of life. }\end{array}$ & $\begin{array}{l}\text { Increasing the presence and } \\
\text { awareness of qualified } \\
\text { infrastructure services in the } \\
\text { Trakya region }\end{array}$ & & \\
\hline 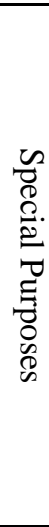 & $\begin{array}{l}\text { "Ecological Domestic Wastewater } \\
\text { Treatment System" to be } \\
\text { established at Namı Kemal } \\
\text { University Degirmenaltı Campus } \\
\text { aims to reduce the ecological } \\
\text { footprint of the wastewater which } \\
\text { is causing pollution of the water } \\
\text { resources which are decreasing } \\
\text { day by day and which is left to the } \\
\text { receiving environment without } \\
\text { treatment as a university and to } \\
\text { make such projects as precedents } \\
\text { to local governments. }\end{array}$ & $\begin{array}{l}\text { The establishment and } \\
\text { successful operation of } \\
\text { "ecological domestic } \\
\text { wastewater treatment system" }\end{array}$ & & $\begin{array}{l}\text { The project aims to } \\
\text { implement an } \\
\text { innovative system, the } \\
\text { technology to be } \\
\text { implemented will be } \\
\text { integrated with the } \\
\text { existing technologies. } \\
\text { But; It is possible that } \\
\text { some unforeseen } \\
\text { problems may arise. }\end{array}$ \\
\hline 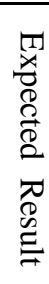 & $\begin{array}{l}\text { Ecological domestic waste water } \\
\text { treatment system } \\
\text { preparatory activities } \\
\text { visibility sign } \\
\text { conclusion report }\end{array}$ & $\begin{array}{l}\text { Establishment of ecological } \\
\text { domestic waste water } \\
\text { treatment system } \\
\text { visibility sign hanging } \\
\text { writing the final report }\end{array}$ & & $\begin{array}{l}\text { The project aims to } \\
\text { implement an } \\
\text { innovative system. }\end{array}$ \\
\hline 龸. & Conduct of visibility activities & & $\begin{array}{l}\text { The state of the water } \\
\text { bills paid by } \\
\text { university and the } \\
\text { areas watered with } \\
\text { wastewater on the } \\
\text { university campus }\end{array}$ & $\begin{array}{l}\text { The project involves the } \\
\text { implementation of an } \\
\text { innovative system } \\
\text { approach. }\end{array}$ \\
\hline
\end{tabular}

\section{Vacuum Sewage Systems}

High underground water levels, low population density, flat areas of settlement are the conditions suitable for the use of vacuum sewage systems. In water protection areas, rivers, lakes or beaches, a vacuum sewage system is most often the best option.

Capacity to be independent from the field, to be able to work (operate) in a small pipe diameter(size), high flexibility and low maintaining cost for the management of the facilities without any problem is its distinctive advantages.

The distinctive advantages of vacuum sewage systems is the capacity to be independent from the field, the ability to work with small pipe diameters, high flexibility, and low maintenance cost for the management of the facilities without any problem.

Small diameter pipeline networks are connected to vacuum stations through separate sanitary systems. Instead of water which is considered to be valuable, air is used as a conductor.

The vacuum system is very flexible and free from natural slope and structural limitations due to its usage of air. The technology also offers the particular advantages as described below. 
Advantages of Vacuum Systems Technology

o Installation of pipeline near trenchless surfaces

oEconomical superiority and fast installation of vacuum lines

$\circ$ With the assistance of trenchless technology, installation of pipeline near trenchless surfaces

oEnables to make a distinction between low pipe diameters, surface water, and others.

oLower hydraulic loading capacity of sewage treatment plants

o Adaptation of variable sewage flows

oLeak-free, interconnected, hygienic construction

$\circ$ Enables the ventilation of waste water

$\circ$ No filtration of underground and rain water

oNo need for backwashing of the network

\section{Other Advantages of the Vacuum Systems}

oNo leakage or smell as it is a closed system

oNo need for supply stations.

o No clogging or sedimentation and no need to clean with water.

o No clogging occurs as there is high speed in sewage pipes.

oIt is a flexible system, and except for the vacuum station, there is no electrical connection.

o Transports better ventilated waste water.

o Transports a large amount of leaking underground water.

○

○Safety Management of the Vacuum Systems

oNo management risks for the operators.

o No direct contact with the waste water.

oNo need to access sewer lines through manholes or closed areas and all equipment is accessible from the ground level.

o Gravity flow systems involves no atmospheric hazards in closed areas.

\section{Usage and Function of the Existing Vacuum Sewage Systems}

Low levels of oxygen, distinct Hydrogen Sulphide $\left(\mathrm{H}_{2} \mathrm{~S}\right)$, physical risks due to potentially explosive levels of methane when entering closed areas, microbes and illnesses, viruses, pathogenic organisms, insects and animals, and bad smell are problems associated with sewer lines and manholes.

Under low vacuum conditions ( -0.3 baro), maximum system performance is ensured by optimized air-water levels.

Under high vacuum conditions (-0.6 baro), minimum air emissions and minimum energy costs are generated.
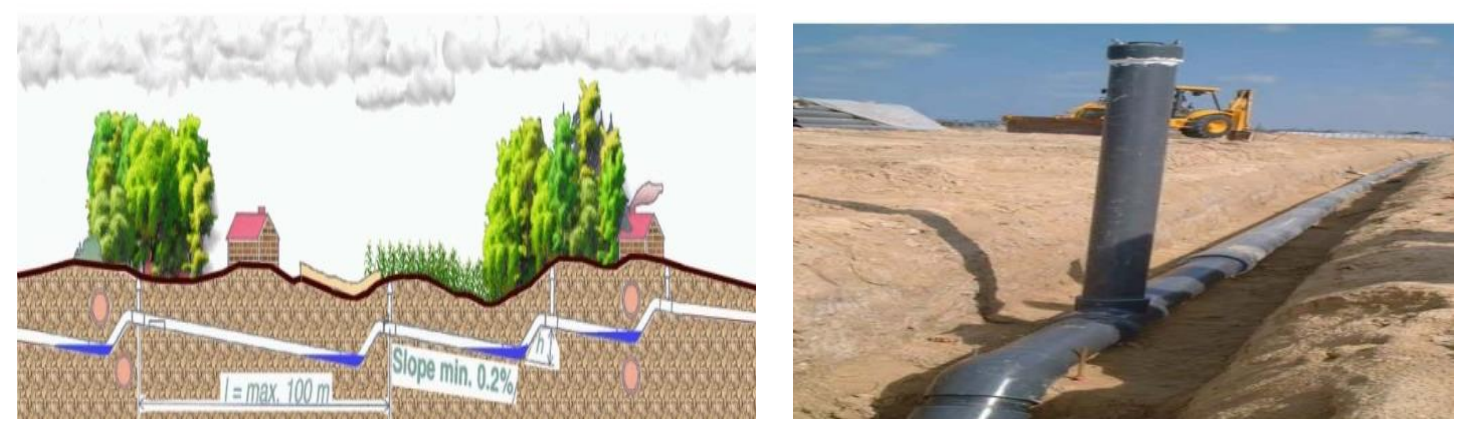

Figure 1. Elements of the vacuum Figure 2. Vacuum sewage lines in a sewage system single trench

No sedimentation

- No need for manholes 
- No need for the maintenance of the sewage network

- Flow speed of the Vacuum network in the closed system is approximately $3-5 \mathrm{~m} / \mathrm{sn}$

Clean water and sewage pipes : Clean water pipes and irrigation pipes could be built through vacuum sewage lines in a single trench.

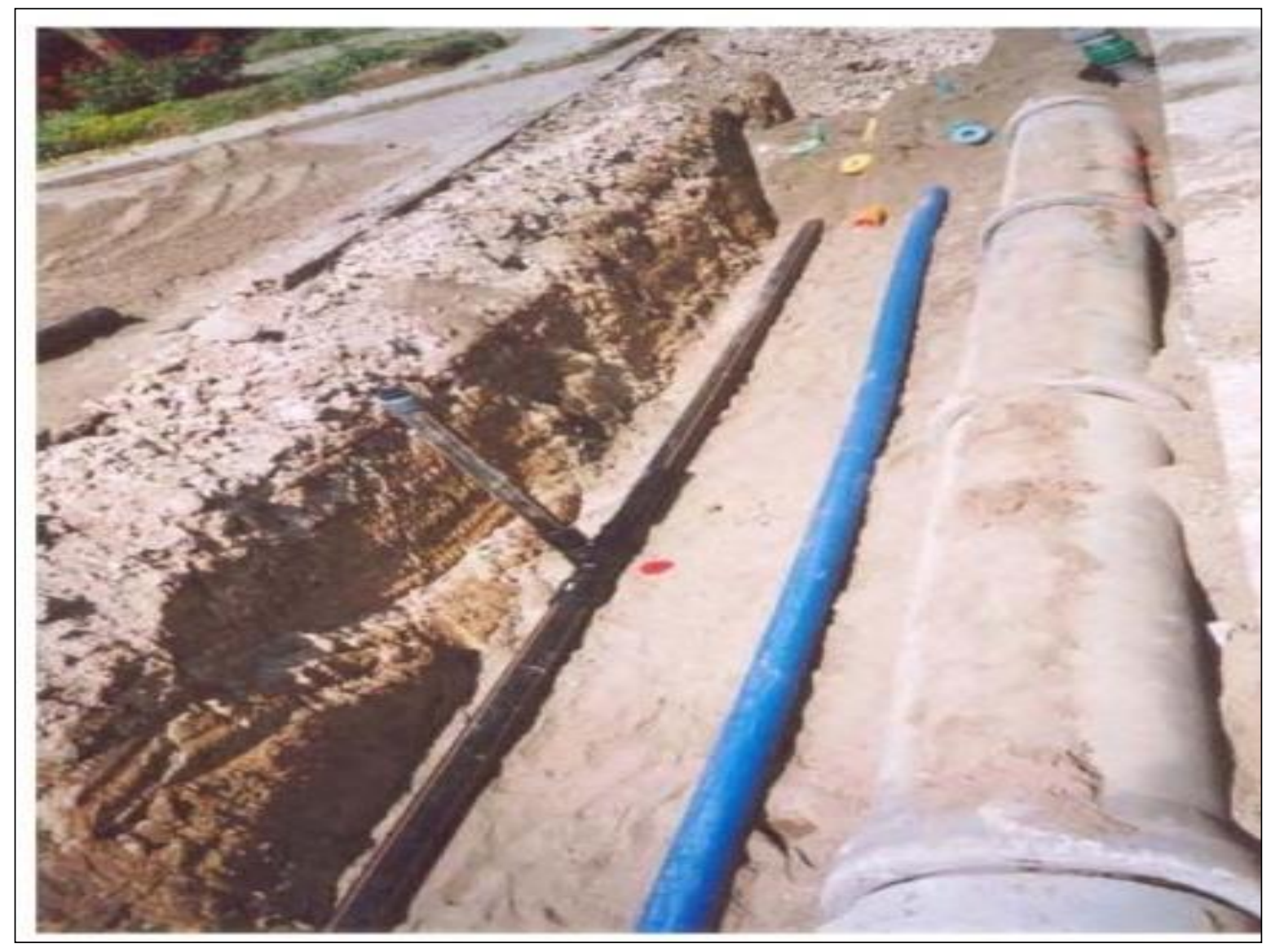

Figure 3. The Clean water and sewage pipes

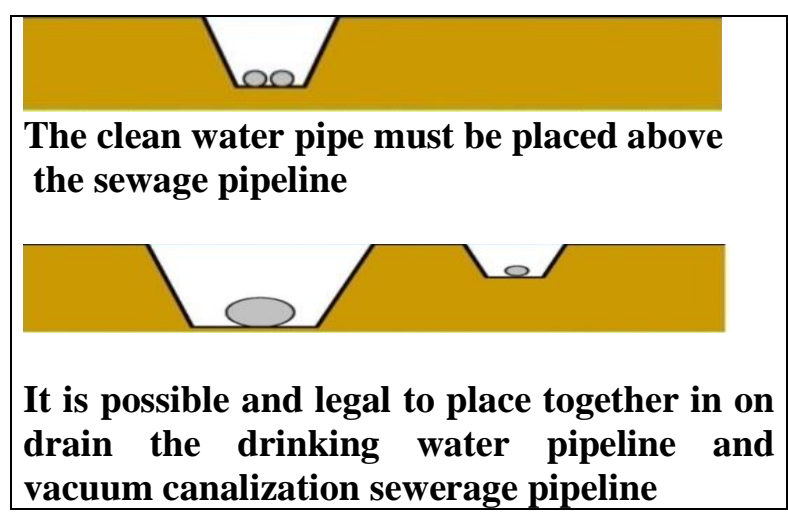

Figure 4. Clean water and sewage pipes in the same trench (vacuum sewage and testing pipe -black small diameter, clean water pipe blue, rain water pipe grey and big diameter, concrete 


\section{Financial analysis of the system}

When the system which is to be built is analyzed, the cost related to the system for Namık Kemal University is calculated as below.

Table 2. Namık Kemal University campus system cost analysis

\begin{tabular}{|ccc|}
\hline Vacuum Cost & EURO $(€)$ \\
\hline Pipes & $400 \mathrm{~m} \times 50 € / \mathrm{m}$ & $20.000 €$ \\
\hline Collection chamber & $10 \mathrm{CC} \times 2.000 €$ & $20.000 €$ \\
\hline Vacuumstation & & $40000 €$ \\
\hline Total & & $\mathbf{8 0 . 0 0 0} €$ \\
\hline Gravity cost & $400 \mathrm{~m} \times 80 € / \mathrm{m}$ & $32.000 €$ \\
\hline Pipes & $30 \times 150 €$ & $4.500 €$ \\
\hline Manholes & $1 \times 40.00 €$ & $40.000 €$ \\
\hline Pump station & & $\mathbf{7 6 . 5 0 0} €$ \\
\hline Total & & \\
\hline
\end{tabular}

Table 3. Vacuum systems enterprise cost

\begin{tabular}{|lc|}
\hline Vacuum sewer system lines (PVC) & $52.000 €$ \\
\hline Inspection pipes and interception valves & $15.000 €$ \\
\hline Collection chambers with T\&M & $20.000 €$ \\
\hline Vacuum station T\&M & $40.000 €$ \\
\hline Vacuum station + customs and transportation procedures of collection chambers & $15.000 €$ \\
\hline TOTAL & $\mathbf{1 3 2 . 0 0 0 €}$ \\
\hline
\end{tabular}

Note: Costs depend on local prices, contractor, and ground factors.

A $10 \%-20 \%$ increase or decrease in the system's cost analysis (because of rate and contractor profit) is possible.

The cost of $1 \mathrm{~m}^{3}$ of waste water including amortization in the system's operation:

- Refinement cost: $0,32 € / \mathrm{m}^{3}$ and

- Operation cost : $0,12 € / \mathrm{m}^{3}$

Total: $\quad 0,44 € / \mathbf{m}^{3}$

\section{Result and Evaluation}

The below aspects are observed after assessing the results.

-Namık Kemal University will recycle its wastewater

- Recycled water could be re-used for irrigation purposes.

- In preventing environmental pollution of the university, it will serve as an example to other governmental organizations.

- Not only will it be economized from the outdoor irrigation water of the University, but also less will be paid for water bills

- As recycled water will be used in the irrigation of the outdoor space, the green area rate per student will increase

- Our ecological footprint as a university will be smaller

- It will reduce environmental pollution

- It will serve as an example to other organizations in the usage of limited natural resources. 
In the current situation $1 \mathrm{~m}^{3}$ city water is 2 Euro. The total water usage for the watered lands is $100.000 \mathrm{~m}^{3} /$ year and the cost of the city water usage is 200.000 Euro/year. In case the used water is refined and integrated into the system again the annual cost becomes 88.000 Euro/year and 112.000 Euro/year is gained annually.

In this case, the cost of the system amortizes itself in 1.5 years.

\section{References}

Adiloğlu, S., 2016. Using Phytoremediation with Canola to Remove Cobalt from Agricultural Soils. Polish Journal of Environmental Studies. Vol. 25, No. 6 (2016), 2251-2254.

Adiloğlu, S., Bellitürk, K., Solmaz, Y., Zahmacioğlu, A., Kocabaş, A., Adiloğlu, A., 2017. Effects of the Various Doses of Vermicompost Implementation on Some Heavy Metal Contents $(\mathrm{Cr}, \mathrm{Co}, \mathrm{Cd}, \mathrm{Ni}, \mathrm{Pb})$ of Cucumber (Cucumis sativus L.). Eurasian Journal of Forest Science. (2017) 5(1): 29-34.

Bottini, N.,Coelho, M. and Kao, J. 2013. Infrastructure bank. Instirute for Government, Economic and Social Research Council.TSPAKB (Capital merkets board of Turkey and Aorporation Union), 2012.

Develi, E.S., 2014. The role of city banks and the importance of development of infrastructure investments at cities, MSc thesis, Cukurova University, Social Science Insfutude, Adana. 36

Sağlam, M.T. and Bellitürk, K., 2003. Su Kirliliği ve Toprak Üzerindeki Etkisi. Alatarım Dergisi, ErdemliMersin, 2 (1): 46-49.

Şimşek, O., and Yinanç, A. 2016. Urban Infrastructure Models and Their Comparison In Different Sectors, BJSS Balkan Joumal of Social Sciences, Intenational Congress of Management Economy and Policy, December.38-54.

Yinanç A. 1997. Suppling of efficiency at local management, Ankara:TODAİE specialization, Thesis, page. 16.

Yinanç A., 1997. Suppling of efficiency at local management, Ankara: TODAİE specialization Thesis, page.4 1. Republic of Turkey Ministry of Environment and Urbanization, Directorate general of geographic information systems, Procect of cify information system standards indication: Theoretical Analysis Report, 2011.

Yinanç, A. 2012. Kentsel teknik altyapı etki değerlendirmesi. Kentsel Dönüşümde Altyapının Önemi,4-9 Kasım 2012, Antalya.

Yinanç, A., 2016. The Financing of Technical Infrastructure Systems European Union Practices and Turkey, BJSS Balkan Joumal of Social Sciences 1. Balkan Intemational Congress of Manageinent Economy and Policy, December. p.30-37.

Yinanç, A., Adiloğlu, S. 2017. Use of Plants in Water Treatment: Models and Pilot Study Case in Kozan District. Journal of Tekirdag Agricultural Faculty VoL:14 say1 (1) p.114-124.

Submitted: 09.10.2017; Accepted: 20.10.2017 